\title{
REGULATION ON FOREIGN OWNERSHIP OF AGRICULTURAL LAND IN THE REPUBLIC OF SERBIA
}

\author{
Dalibor Krstinićl, Jovana Vasiljković ${ }^{2}$, Ana Langović Milićević3 \\ *Corresponding author E-mail: krstinicdalibor@yahoo.com
}

A R T I C L E I N F O
Review Article
Received: 04 May 2020
Accepted: 18 May 2020
doi:10.5937/ekoPolj2002553K
UDC 332.22:349.41(497.11)
Keywords:
foreign citizen, right to property,
agricultural land, real estate

JEL: K11, K15, K250, O13, P52

\begin{abstract}
A B S T R A C T
The research topic in the first part of the paper is the regulation on foreign ownership of agricultural land in XIX and XX century, while the second part focuses on analysing foreign ownership regulation in XXI century. The paper aims to provide an overview of the rights of foreign citizens to acquire real estate,with an emphasis on their right to acquire agricultural land in the Republic of Serbia through a methodological-theoretical framework. The legislation which has regulated the said legal concept in our region in different ways throughout history will be viewed through the prism of history by using the historical method. The current regulations which regulate the said subject matter in the Republic of Serbia will be analysed by the normative method, in addition to the use of content analysis that will complete this research through the systematic anlysis of literature. The conclusion will sum up the results of the research which point to the fact that even though in certain periods foreign citizens were entitled to acquire agricultural land, their right was never complete as it implied meeting certain requirements.
\end{abstract}

(C) 2020 EA. All rights reserved.

1 Dalibor Krstinić, Ph.D. Assistant professor, University of Business Academy, Faculty of law of commerce and judiciary, Geri Karolja Street, no. 1, 21000 Novi Sad, Republic of Serbia, Phone: +381 6413943 16, E-mail: krstinicdalibor@yahoo.com, ORCID ID (https:// orcid.org/0000-0002-9731-9178)

2 Jovana Vasiljković, Doctoral candidate University of Business Academy, Faculty of law of commerce and judiciary, Geri Karolja Street, no. 1, 21000 Novi Sad, and legal secretary of Faculty of Pharmacy, Trg Mladenaca 5, 21101 Novi Sad, Republic of Serbia, Phone:+38169711835 E-mail: vasiljkovicjovana5@gmail.com, ORCID ID (https://orcid. org/0000-0003-0254-3685)

3 Ana Langović Milićević, Ph.D., Full professor, University of Kragujevac, Faculty of Hotel Management and Tourism in Vrnjačka Banja, Vojvođanska 5A, 36210 Vrnjačka Banja, Serbia. Phone: +381 65 5006080. E-mail: ana.langovic@kg.ac.rs, ORCID ID (https://orcid. org/ 0000-0003-3610-1332) 


\section{Introduction}

Real estate forms part of the territory of a country and serves as the basis for many business activities such as agriculture, construction, traffic etc. For this reason it has a great economic, political and security importance for every country. This results in countries taking a very reserved stand when it comes to the possibility of foreign citizens acquiring real estate on their territory. A country's right to restrict the right of ownership of immovable property to foreign citizens is recognized in international law, and confirmed in practice. (Stanivuković, 1989). Thereby the restrictions made while acquiring property by foreign citizens are varied. For example, foreign citizens in Mexico can't buy real estate in $100 \mathrm{~km}$ border area, i.e. $50 \mathrm{~km}$ off the coast of the sea. The said restriction was imposed due to security reasons. In Brasil the law also stipulates that foreign citizens may not acquire real estate in the areas of critical importance for security (Varadi, 1987). Apart from security and economic reasons, social reasons also affect the regulation of this matter. For instance, immovable property such as agricultural, construction and forest land, as well as the land in the tourist areas is restricted in number, and its price depends on the demand. For this reason free sale to foreign citizens who have higher purchasing power than the local population, might lead to the increase in prices of the said types of immovable property, which in the long term would result in forcing out local subjects from important branches of economy, such as agriculture, tourism, construction, etc. Agriculture represents an economic branch with specificities and developments that do not comply with the classical economic laws, at least from the perspective of production and prices (Drăgoi et al., 2018). Therefore, many countries including the underdeveloped ones restrict the ownership rights of foreign citizens to immovable property (Stanivuković, 2012).

As for the foreign citizens' rights to acquire ownership of agricultural land in the Republic of Serbia, this right has changed through the decades from a restrictive attitude which meant that foreign citizens could not acquire this right through a legal transaction, to the attitude that foreign citizens may acquire property on certain conditions. According to the provision of article 2, paragraph 1 of the Law on Agricultural Land (Official Gazette of the Republic of Serbia no. 62/06, 65/08 - other law, 41/09, 112/15, $80 / 17$ and 95/18 - other law) agricultural land denotes the land used for agricultural production, such as arable land, orchards, gardens, vineyards, pastures, meadows, fishponds, reeds and marshes, as well as the land intended for agricultural production through an adequate planning law. It is a relevant piece of information that out of the total available land in the Republic of Serbia up to $72 \%$ is taken up by agricultural land, and $64,3 \%$ by used agricultural land, based on which it can be concluded that it dominates in our region (Đurić, Njegovan, 2016). Agriculture and hence agricultural land as its most important resource have a crucial influence on the general development of our community especially in the process of implementing reforms and transition. The above stated points to the fact that agriculture is the most valuable potential of the Republic of Serbia, which is confirmed by the data on the area occupied by it, as well as by the number of people whose livelihood depends on that activity, and the income 
made by this particular branch of economy (Vukićević, et al., 2011). On the other hand, changing the purpose of arable agricultural land into construction land is a current issue which needs to be dealt with in more detail by our legislator by the introduction of positive legal regulations (Počuča, Draškić, 2015).

In addition, this is a very current topic today given the fact that the Republic of Serbia is a candidate for EU memebership, and the Stabilisation and Association Agreement prescribes coordinating regulations with the EU law. Therefore, coming into force of the Stabilisation and Association Agreement between European communities and their member states on the one side, and the Republic of Serbia on the other side (Official Gazette of the Republic of Serbia, International Agreements no. 83/2008), influenced the regulation of the subject matter in question, which will be discussed in more detail in this paper.

\section{Aim of the paper}

The basic aim of this paper is the study and analysis of the particularity of the legislation which regulates the rights of foreign citizens to acquire ownership of agricultural land in the Republic of Serbia through a methodological-theoretical framework. Apart from this the aim of the paper is also the study of the social and economic significance, as well as the chronological monitoring of the legislation development in this area of law.

\section{Methodology}

In order to get a good understanding of the legal concept in question it is necessary to study its historical growth, which is why the historical method will be used in the research. The historical method uses basic facts through the chronology of events, in this case the rights of foreign citizens to acquire ownership of agricultural land in the Republic of Serbia, as well as the analysis of the regulations and concepts throughout the years. The historical method provides the understanding of the sense of the legislation which has regulated this matter in different ways. The said method will be completed by the normative method which will be prioritised while studying this legal concept. The normative method places special emphasis on the analysis of the current national laws which play a relevant role in the regulation of the studied matter. Alongside the stated methods, content analysis will also be used for the purpose of analysing the terms relevant to the topic of the paper, such as the concept of a foreign citizen as property acquirer, as well as adequate literature, to complete this research.

\section{The concept of a foreign citizen as property acquirer}

A foreign citizen is normally considered to be a person who is not a domestic national, which means - a person who is a foreign citizen or a person without citizenship. The stated represents the classic interpratation of the concept of foreign citizens and it most often comes into play in the matters of determining their legal status (Stojanović, Pop Georgiev, 1980). Pursuant to the Law on Resolving Conflicts of Law with Regulations of Other Countries (Official Gazette of SFRY, no.43/82 and 72/82 - as amended., 
Official Gazette of SRY, no. 46/96 and the Official Gazette of RS, no. 46/06 - other law) a natural person with a foreign citizenship and a Serbian citizenship is considered a Serbian national, and if they have two or more citizenships they are considered to be the citizens of the country in which they have a domicile. According to the Law on Foreigners (Official Gazette of RS, no. 24/18, 31/19) a foreigner is any person who does not have the citizenship of the Republic of Serbia.

In certain countries during wartime, in accordance with the legislature of those countries, a foreigner is considered any person with a domicile on enemy territory and the territory occupied by the enemy, regardless of the person's citizenship. It is the so called enemy foreigner, whose property is blocked during the war by the domestic country in its own territory and against whom certain measures are taken to the end of weakening the economic potential of the enemy country. In certain countries during economic crisis, according to the regulations of the said foreign countries, a foreign citizen is considered to be any person with a domicile in a foreign country, regardless of the person's citizenship (Stojanović, Pop Georgiev, 1980).

In the domestic territory of a country not all the rights are equally available to the domestic nationals. In consideration of the rights available to foreign citizens and the terms under which they can be granted those rights, all the rights can be categorized into three basic groups. The first group are the absolutely reserved rights, or the rights the owners of which may not be foreigners under any condition, since those rights are absolutely unavailable to them. They are reserved strictly for the domestic nationals for it is through them that the influence on social-economic structure or the security of a country can be exerted. The second group are relatively reserved rights. These are the rights that are available to foreign citizens if certain requirements are met, such as reciprocity for instance. The next group of rights are general rights. More precisely, those are the rights which are available under equal terms to domestic nationals and foreign citizens alike (Stojanović, Pop Georgiev 1980).

Foreign citizens mainly acquire the right of ownership over real estate under the condition of reciprocity, or mutuality. The forms of reciprocity differ according to the way they were created, thus accounting for three types of reciprocity in international relations: diplomatic, legal and factual. Diplomatic reciprocity is formed based on an international agreement when two or more countries mutually commit to granting the citizens of the other signatory party the rights which are contained in and agreed by the agreement. The legal reciprocity is formed when the mutuality is established on a legal level, and factual when the acquisition of certain rights by foreign citizens is factually obtained in practice (Panić, 2017).

\section{Foreign ownership of agricultural land in Serbia during XIX and XX century}

The rights of ownership of real estate and other real rights, the so called sectoral rights were not granted to foreign citizens in neither slavery nor feudalism. It was the French bourgeois revolution of 1979. that marked the turning point in this regard. However not 
even then were those rights recognised to foreign citizens in every country, and even if recognised they did not have the characteristics of universal rights. In our region, or in our country these rights were recognised for the first time in 1844. (Jezdić, 1982). Namely, with the codification of the civil law, i.e. with the enactment of the The 1844 Civil Code, the issue of the property of foreign citizens is regulated by the legislator as well. The provision of article 15 of the Civil Code prescribes that foreign citizens have the right to acquire ownership of real estate, including agricultural land, that is guaranteed to them under the same conditions as to Serbian nationals. This kind of, arguably, liberal attitude concerning the rights of foreign citizens to real estate was altered in 1852, by the enactment of the Regulations against the abuse of foreign citizens, concerning the immovable property in Serbia on the name of foreigners (Srpske novine no. 96/152). These regulations prohibited foreign citizens from acquiring ownership of property in the future, while the already acquired property had to be alienated. The system which was introduced by these regulations implied absolute prohibition for foreigners in terms of acquiring ownership, and it particularly concerned those foreign citizens who purchased land on the name of Serbian nationals. For this category of foreign citizens there is a requirement of mandatory registration of such purchased immovable property within the period of three months, to be advised of the possibility of public sale. The only stipulated exception concerning foreign citizens was their right to own a house pursuant to a contract (Carić, 2006).

The rights of foreigners to property in Yugoslavia between the two world wars were governed by the laws in the finance section. Hence a provision of article 48 of the Yugoslav Budget Law of July-August 1923, prescribed that the rights of foreigners to acquire property are to be regulated in a universal manner for the whole country, taking into account the difference dependent on the location of the immovable property. If it is located in the border or coastal zone within $50 \mathrm{~km}$, foreigners were allowed to acquire property only if they were granted approval of two ministers, minister of the army and minister of the navy. The other law that governed the foreign ownership of immovable property is the provision 94 of the Finance Law for 1925-26 which did not introduce any essential changes in comparison to the previous law other than it stipulated the possibility for the foreigners buying estates in Southern Serbia to settle permanently based on the registration filed with The Court of First Instance. Following the repeal of this provision the new Finance Law came into force for 1927-28 which regulated the same subject matter. More precisely, after the repeal of the provision of 1928, only the special regime regarding real estate in the border and coastal area, and the rigorous sanctions involving the breach of the said regime were abolished which means that the general regime of acquiring real estate in the interior zone for foreign citizens remained the same. Foreign citizens were able to acquire right to foreign ownership in Yugoslavia until the beginning of World War II only if the reciprocity requirement was met (Carić, 2006).

Following World War II Jezdić (1982) states that regarding the right of foreign citizens to acquire ownership of immovable property, there are two periods according to our law. The first period refers to the period after the national revolution was carried out, 
when foreign citizens were able to acquire ownership of immovable property if granted the approval of the competent authority, ie. the President of the Economic Council. The second period is the period after the implementation of the nationalization of the foreign citizens' immovable property in which this right is dealt with in different ways depending on whether the right to acquire ownership refers to the real estate that was acquired by legal transactions inter vivos - pursuant to an agreement on purchase, gift or exchange or mortis cauza i.e. based on inheritance. In the said second period, the right to acquire ownership of immovable property in Yugoslavia by inter vivos transactions was at first treated as an absolutely reserved right, i.e. as a right that may not be enjoyed by foreign citizens.

Of all the means available to acquire property in socialist Yugoslavia, a foreign citizen was able to acquire the right to ownership of land or buildings only by means of inheritance - legal and testamental. This possibility was recognized to foreign citizens by a provision of article 8 of the Law on Land and Building Transactions of 1955 . (Official Gazette of SFRY no.19/1955), and by a provision of article 5 of the Law on inheritance of 1955, a provision of article 5 (Official Gazette SFRY, no.20/55), except that there were certain restrictions. Namely, according to a provision of article 159, paragraph 2 and 3 of this Law, a foreign citizen was not allowed to own more agricultural land based on their inheritance than a Yugoslav national, therefore a foreign citizen was allotted a corresponding monetary compensation in exchange for the agricultural land that may not be owned.

Pak (1989) states that in the earlier periods foreigners were allowed to acquire ownership of real estate by means of a contract, but only exceptionally. More precisely, in the period between 1962 and 1967, foreign citizens were able to acquire buildings and the right to use land for rest or recuperation purposes only on the condition of obtaining approval of the Secreteriat for Commerce and Toursim and the consent of the Federal Secretariat for Internal Affairs (article 16 of the Bylaw on acquiring rights to buildings and apartments and lands by foreign citizens and foreign legal persons, Official Gazette of SFRY, no.53/62). This right was abolished in 1967, by the enactment of the Law on Changes and Amendments to the Law on Land and Building Transactions (Official Gazette of SFRY no. 1/67), while in the period from 1974 to 1982 the right to property of a family-owned building and the right to use land was recognized to natural persons with merits in the Yugoslav Resistance. The said right was governed by the Law on Land and Building Transactions (Official Gazette of SFRY no. 11/74), and the same provisions were annulled by the enactment of the Law on the Elements of Property Law Relations in 1982. (Official Gazette of SFRY, no. 6/80, Official Gazette of SRY, no. 3/90, no. 29/96 and the Official Gazette of the RS, no. 115/2005 - other law). A provision of article 82 of this Law regulates the legal status of foreign citizens in the matter of them becoming owners of the right to property. According to paragraph 2 of the said article, in the territory of SFRY all natural persons were entitled to ownership of land and buildings on two conditions as follows: the existence of reciprocity and acquiring that right by inheritance. This kind of legal option was stipulated by the legislator unless otherwise prescribed 
by the international agreement, and if that is the case then the provisions of the said international agreement were applied and not the provisions of article 82, paragraph 2 of the Law on the Elements of Property Law Relations.

It is relevant to point out that the legislator did not specify the form of mutuality, i.e. reciprocity in question. It can only be assumed that it referred to that form of mutuality that provides most possibilities for the foreign citizen to acquire ownership of real estate, i.e. that the matter of whether the country of the foreign citizen treats Yugoslav nationals in the same way as the nationals of other countries will be investigated. Another interpretation of the reciprocity principle implied a request for the foreign country to treat Yugoslav nationals in the same way as Yugoslavia treats foreign citizens which would lead to citizens of some countries not being able to acquire ownership of real estate in Yugoslavia (Đurđev, 1997). The previously mentioned Law on the Elements of Property Law Relations which was enacted in 1982 was changed and amended a few times, and in those changes and amendments of 1990 it is stipulated that every foreign legal or natural person is required to perform a business activity in Yugoslavia in order to acquire ownership right of real estate. However, the legislator did not define the notion of "performing a business activity in Yugoslavia", so it was considered that this notion included all types of direct investments, since those are the kind of activities that imply presence in Yugoslavia, and in order to perform them there usually has to be a real estate involved (Stanivuković, 1996). Nevertheless, any real estate except for agricultural land was subject to acquisition. On the other hand, in a privatization process a foreign citizen was able to buy a public company registered for performing agricultural activity that, in addition, owns the rights to dispose of publicly owned agricultural land. Thus a foreign citizen despite not being a direct owner of real estate was able to effectively exert their influence on the decision making process through a legal person who was the direct owner and had the authorizations of an owner. In order to avoid the previously described exploiting of loopholes it was necessary to regulate with precision the foreign ownership of agricultural land.

\section{Foreign ownership of agricultural land in Serbia in XXI century}

The question of enacting a universal law that would regulate foreign ownership of agricultural land in the Republic of Serbia was materialised by the enactment of the Law on Agricultural Land in 2006 ( Official Gazette of RS, no. 62/06). With this law our legislator restricted the right of foreign ownership of real estate in the Republic of Serbia intended for agricultural production. In the first article the legislator already specifically states that "The owner of agricultural land may not be a foreign natural, or legal person." From this provision it ensues that as of the date of its coming into force foreign citizens may not acquire neither ownership rights of agricultural land nor a legal transaction, i.e. contract, nor inheritance, since they can not own the said entities.

Nevertheless, this law had certain flaws since it did not account for a possible form of foreign ownership of agricultural land, which is through a legal person that was established only for the purpose of performing a certain transaction instead of their 
founder and to act as owner in their place. Therefore if the potential acquirer of the land is a foreign citizen there is way to find a loophole since the agricultural land is only formally owned by a domestic legal person when in reality it is actually controlled by foreign citizens (Stanivuković, 2012). More specifically, according to a provision of article 3 of the Law on Foreign Trade Transactions of the Republic of Serbia (Official Gazette of RS, no. 36/09, 36/11, other law and 88/11) foreign citizens in Serbia were able to found legal entities with the seat in Serbia, i.e. that are registered in the Republic of Serbia and that are considered domestic.

In addition, the Law on Agricultural Land did not account for the consequences of acquiring agricultural land by means of inehritance. This is debatable since a provision of article 7 of the Inheritance Law (Official Gazette of RS, no. 46/95, 101/03 - Decision of Constitutional Court of RS and 6/15) prescribes that a foreign citizen has the same inheritance status as a domestic national. Article 212 of the same law prescribes that inheritance passes down to heirs by force of law at the moment of death of the decedent. If the inheritance is agricultural land and the heir is a foreign citizen, by force of law he or she become the owner of that land, which opposes the provision of article 1 of the Law on Agricultural Land of 2006. In order for the said provision to be valid, the inherited real estate would have to be confiscated from foreign citizens, but there is no procedure prescribed to regulate that matter, neither to regulate the right to compensate for the value of the seized property. Also, the said law lacks provisions which would regulate the procedure in case of a domestic owner of agricultural land losing domestic citizenship due to gaining citizenship of another country. Due to the lack of provisions that would regulate the above mentioned occurrences, confiscating the inherited agricultural land would open the issue of the right to protection of property as a human right (Stanivuković, 2012).

Due to the fact that property is one of the basic human rights of individuals and legal persons alike, countries' constitutions pay special attention to the protection of this law. More specifically, by a provision of article 85, paragraph 1 , of the Constitution of the Republic of Serbia (Official Gazette of RS, no. 98/06), the legislator prescribes that foreign natural and legal persons may acquire property in accordance with the law or the international agreement.

Thus pursuant to a provision of article 82a, paragraph 1, of the Law on the Elements of Property Law Relations of 2005, the legislator prescribes that foreign natural, and legal persons that perform their business activities in the Republic of Serbia, on the condition of reciprocity may acquire rights over immovable property on the territory of the Republic of Serbia which they need in order to perform those activities. However, the Law on Agricultural Land of 2006 is lex specialis compared to the Law on the Elements of Property Law Relations since, as already mentioned, it specifically states that the owner of agricultural land may not be a foreign natural or legal person. Consequently, a question ensues whether it is good in a legally technical sense to have this kind of norm in the Law on Agricultural Land which regulates planning, organization, protection and use of agricultural land, as well as other relevant issues thereof, and not in the law which regulates proprietary relations (Baturan, 2013a). 
When it comes to acquiring ownership rights over immovable property for business purposes then this acquisition represents an investment, which can be foreign, hence the person acquiring it can be a foreign investor. Investors who are foreign natural or legal persons may acquire right over property, and other real rights over immovable property located on the territory of our country, and in accordance with the Constitution and the law, while in respect of their own investments foreign investors have the same status and the same rights and obligations as domestic investors. However, investment shall not be subject to expropriation whether directly or indirectly by measures the aim of which is the effect equal to expropriation (article 5 and 6, of the Law on Investments, Official Gazette of the RS, no. 89/15, 95/18). Expropriation is a form of restricting rights over property, or a forced deprivation of property.

The crucial issue regarding expropriation is the just compensation owed to the owner of the confiscated immovable property (Trgovčević-Prokić, Počuča, 2016). In that respect when the investor is a foreign legal or natural person they have the rights, after having regulated all the prescribed obligations, to a compensation for expropriation, i.e. other measures with a similar effect (article 9, Law on Investments, Official Gazette of the RS, no. 89/15, 95/18).

A very important, arguably crucial milestone for the Republic of Serbia is the fact that in 2008 it signed and ratified the Stabilization and Association Agreement with the European Union (hereinafter Stabilization and Association Agreement) which came into force in 2013. In accordance with the politics of the European Union which is reflected in the creation of a universal market, it requests from all member states to repeal the provisions which stand in the way of the free development of economic relations, and all to the end of creating a universal market (Resolution on Accession to EU, Official Gazette of RS, no. 112/04).

In order to meet the requirements the Republic of Serbia committed to changing its legislation with reference to the foreign ownership of real estate and of agricultural land in order to provide the same treatment to the citizens of EU states as to its own citizens within four years as of the date of the coming into force of the Stabilization and Association Agreement. However, the deadline that the Republic of Serbia set for repealing the restrictions on the purchase of agricultural land for foreign citizens represents a premature, even a reckless step that may have farfetched and negative effects on the agricultural development and agricultural land alike (Vukićević, et al., 2011). With respect to the deadline by which future member states will have to repeal the restriction on the purchase of agricultural land for foreign citizens, they mostly set a more extended deadline for the repeal of the restriction. For example, Hungary while still in the negotiation process for the accession to EU, reached a decision by which foreign citizens would be able to buy agricultural land only upon the expiration of a ten-year period of its EU membership. Hungary became a member state on May 1, 2004, and it was not until June 21, 2013 that it adopted the Law on Agricultural and Forestry Land Transactions, imposing thereby to foreign citizens the terms for acquiring ownership of land, which curtailed one of the basic freedoms of the European http://ea.bg.ac.rs 
Union - freedom of capital transactions. For that reason, the European Union initiated court proceedings against Hungary (Spalević, 2013/2014). Denmark made it possible for foreign citizens to buy agricultural land on the condition that they live in that country for at least two years. The government of Denmark pointed out that it is in the public interest for the national legislature to try and preserve the farming of agricultural land by its owners, who live on that land, to ensure that agricultural land be farmed exclusively by its owners, to preserve a permanent agricultural community as a measure of planning of cities and the country, and to improve the rational use of available agricultural land, which will reduce the pressure put on the same land (Case C-370 05, 2013/2014). During the negotiation process for accession to EU, the Republic of Croatia also extended the deadline for the liberalization of land sale to foreign citizens, thus it remain unclear why Serbia agreed to authorize the sale of agricultural and forest land before becoming a member of the European Union. It can be argued that this step would lead to domestic farmers being left to their own devices in the market "game" with a far more powerful competition from EU (Rankov, 2013/2014). The current low prices of agricultural land will be an incentive for foreign citizens who will be able to buy agricultural land at more than reasonable prices, and our farmers will be forced to work for foreigners. Moreover, by purchasing agricultural land located on the outskirts of big cities, foreigners will gradually turn it into construction land, which will affect the reduction of the surface of that land, as well as the reduction of products and income (Vukićević, et al., 2011).

Along with the repeal of the restriction on foreign acquisition of agricultural land, the arrival of big manufacturers ready to offer higher prices to small estates is to be expected. It is assumed that in that case domestic manufacturers would be forced to pay more for agricultural land (Baturan, 2013b). Based on the commitment that the Republic of Serbia made when concluding the Stabilization and Association Agreement, our legislator enacted the Law on amendments to the Law on Agricultural Land that was adopted in August 2017, and started being applied as of September 1, 2017 (Official Gazette of RS, no. 80/2017). Even the provision of the article 1 paragraph 4 of this law emphasizes that the said law was enacted in order to comply with the obligation prescribed by the Stabilization and Association Agreement. The said provision stipulates that "The owner of agricultural land may not be a foreign natural or legal person, unless otherwise prescribed by this Law in accordance with the Stabilization and Association Agreement between their member states on the one side and the Republic of Serbia on the other side." However, from the added article 72d of this Law it is clear that the citizens of the European Union are discriminated both formally and essentially compared to domestic nationals. This results from the fact that the legislator differentiated between the number of conditions to be met for domestic nationals on the one hand, and foreign citizens on the other. Those conditions have to be fulfilled cumulatively, whereas they actually represent barriers for foreigners when entering the market of agricultural land in the Republic of Serbia. Our legislator prescribed that a citizen of the European Union may acquire agricultural land, of over 
two hectares of land area, if having been permanently settled in the municipality in which the transaction of the agricultural land takes place for not less than ten years, if having farmed the agricultural land that is the subject of the legal transaction for not less than three years, with or without compensation, if having had a registered agricultural estate with an active status as the holder of a family agricultural estate, pursuant to the law that regulates agriculture and rural development for not less than ten years, without discontinuity, and if owning the mechanization and equipment for agricultural production. Baturan (2017) states that this norm discriminates not only against the citizens of the European Union but our citizens as well since it restricts the rights of domestic nationals who own agricultural land. This restriction can be viewed in the fact that domestic nationals may not sell agricultural land to the citizens of the European Union, at probably higher prices, which is not to be disregarded. On the other hand, it is relevant to point out that the legislator specifically stated which agricultural land may not be the subject of the legal transaction, and that is the land which pursuant to the law was designated as construction land, which belongs to protected landmarks and which borders military facilities and military installations, military infrastructure or Ground Security Zone. In addition, in the event of sale of agricultural land to a citizen of the European Union, the legislator prescribes that the Republic of Serbia has the right of first refusal. In respect of this right, a question is raised in what way the Republic of Serbia benefits from the function of right of first refusal.

By introducing amendments in 2017, our legislator temporarily disabled foreign citizens from acquiring ownership rights to agricultural land, which means that no long-term changes were made. It is our opinion that the Republic of Serbia will have to equalize the rights of foreign citizens, i.e. citizens of the European Union with the rights of domestic nationals with respect to acquiring ownership rights of real estate, including agricultural land. The question arises whether the legislator will do so under the pressure of the European Union or court authority.

\section{Conclusion}

Regarding the conducted research which referred to the foreign acquisition of ownership of agricultural land there is an evident shift of legal regulations that advocated different "opinions" starting from the ones that advocated the position that foreign citizens should not be equal to domestic nationals in reference to ownership rights of agricultural land, to the more liberal approach to the issue. Nevertheless, even though foreign citizens were, at one point, allowed to have free access to real estate, including agricultural land, that freedom was never complete since it involved meeting certain requirements. For example, the restrictions that were, in an earlier period, prescribed for foreigners wanting to acquire ownership of real estate, including agricultural land, were mitigated in the former SFRY up to a point, by amending the Law on the Elements of Property Law Relations of 1982, and then they were additionally "loosened" by the amendments of the same Law of 1990 and 1996. On the other hand, despite the expressly stated restriction stipulated by the Law on Agricultural Land of 2006 according to which 
foreign natural or legal persons may not be owners of agricultural land, foreign citizens managed to indirectly obtain large areas of arable agricultural land, which arguably resulted in a risk for potential investors of the manner in which domestic courts would construe this norm in the future.

From the latest amendments to the said Law, and in accordance with the Stabilization and Association Agreement, it is evident that the amendments of 2017 cannot introduce long-term changes and that our legislator will have to equalize the rights of the citizens of the European Union with the rights of domestic nationals with regard to acquisition of ownership rights to agricultural land. However, we feel that it is necessary for our legislator to move this matter from the Law on Agricultural Land, which regulates the protection, planning and organization of agricultural land to the Law on the Elements of Property Law Relations which, among other things regulates foreign citizens' right to property, hence it would be "suited" for this Law to regulate the rights of foreign ownership of agricultural land.

The authors believe that our market of agricultural land is appealing to foreign investors, due to the relatively reasonable prices in comparison to other markets of the European Union member states, and to certain natural features, such as climate conditions, but also due to the social advantages reflected in the relative formation of the democratic institutions. To sum up, we conclude that with reference to property rights of foreign citizens to agricultural land in the Republic of Serbia it is necessary to primarily bear in mind the real interest of the state and its needs, but also the extent to which foreign citizens really take an interest in the market of agricultural land in the Republic of Serbia.

\section{Conflict of interests}

The authors declare no conflict of interest.

\section{References}

1. Baturan, L. (2017). The right of foreign persons to acquire ownership of agricultural land in Serbia following the 2017 legal amendments. Proceedings of the Faculty of Law, Novi Sad, 51(3), 1153-1175. doi: 10.5937/zrpfns51-15238 [in Serbian: Baturan, L. (2017). Pravo stranih lica da stiču svojinu na poljoprivrednom zemljištu u Srbiji nakon zakonskih novela iz 2017. godine. Zbornik radova Pravnog fakulteta, Novi Sad, 51(3), 1153-1175].

2. Baturan, L. (2013a). Economic analysis of the ban on foreigners acquiring property rights on agricultural land in Serbia. Economics of Agriculture, 60(3), 479-491.

3. Baturan, L. (2013b). Transfer of ownership rights on agricultural and forest land to foreign persons in Serbia and other countries of the region. Proceedings of the Faculty of Law, Novi Sad, 47(2), 515-531. doi: 10.5937/zrpfns47-4446, [in Serbian: Baturan, L., (2013b). Prenos prava svojine na poljoprivrednom i šumskom zemljištu na strana lica u Srbiji i drugim zemljama regiona. Zbornik radova Pravnog fakulteta, Novi Sad, 47(2), 515-531. 
4. Caric, S., (2006). The property right of foreigners to real estate. S. Carić, Belgrade. [in Serbian: Carić, S., (2006). Pravo svojine stranaca na nepokretnosti, S. Carić, Beograd].

5. Djurdjev, D. (1997). Foreigners' Right to Property, Right, Law - theory and practice, 14(6) 23-27. [in Serbian: Đurđev, D. (1997). Pravo svojine stranaca na stvarima, Pravo : teorija i praksa, 14(6), 23-27].

6. Djuric, K., \& Njegovan Z. (2016). Agricultural Economics. Faculty of Agriculture, Novi Sad. [in Serbian: Đurić, K., \& Njegovan Z. (2016). Ekonomika poljoprivrede. Poljoprivredni fakultet, Novi Sad].

7. Drăgoi, M. C., Andrei, J. V., Mieilă, M., Panait, M., Dobrotă, C. E., \& Lădaru, R. G. (2018). Food safety and security in Romania-an econometric analysis in the context of national agricultural paradigm transformation. Amfiteatru Economic, 20(47), 134-150.

8. Jezdic, M. (1982). Private international law. Science Book, Belgrade. [in Serbian: Jezdić, M. (1982). Međunarodno privatno pravo. Naučna knjiga, Beograd].

9. Pak, M. (1989). Private International Law, Scientific Book, Belgrade. [in Serbian: Pak, M. (1989). Međunarodno privatno pravo, Naučna knjiga, Beograd].

10. Panic, M. M. (2017). Aliens' rights to acquire real property rights. Proceedings of the Faculty of Law, Novi Sad, 51(3), 1111-1124. [in Serbian: Panić, M. M. (2017). Prava stranaca da stiču pravo svojine na nepokretnostima. Zbornik radova Pravnog fakulteta, Novi Sad, 51(3), 1111-1124. Pravni fakultet, Novi Sad].

11. Pocuca, M., \& Draskovic, B. (2015). Changing the use of agricultural land in construction - practice and tendencies. Economics of Agriculture, 62(2), 497-511. doi: 10.5937/ekoPolj1502497P

12. Rules Against Abuse of Foreign Subjects, Immovable Property in Serbia Taking Other Name, Serbian Gazette no. 96/1852. [in Serbian: Pravila protiv zloupotrebljenija stranih podanika, nepokretna dobra u Serbiji na tuđe ime, Srpske novine br. 96/1852].

13. Rankov, M. (2013/2014). Impact of the European integration process on the agricultural sector in the countries of Central and Eastern Europe, Student's Journal of Business Law, 4(1), 23-27. [in Serbian: Rankov, M. (2013/2014). Uticaj procesa evropskih integracija na sektor poljoprivrede u zemljama Centralne i Istočne Evrope, Studentska revija za privredno pravo, 4(1), 23-27].

14. Resolution on Association with the European Union, Official Gazette of the Republic of Serbia, No. 112/04. [in Serbian: Rezolucija o pridruživanju Evropskoj uniji, Službeni glasnik Republike Srbije, br. 112/04].

15. Stanivukovic, M. (1989). Property rights of foreigners in real estate in the SFRY and the impact of the new Foreign Investment Law on this matter. Legal Life, 38(8/10), 1379-1390. [in Serbian: Stanivuković, M. (1989). Svojinska prava stranaca na nekretninama u SFRJ i uticaj novog Zakona o stranim ulaganjima na ovu materiju. Pravni život, 38(8/10), 1379-1390]. 
16. Stanivukovic, M. (2012). Foreigner as acquirer of property rights in real estate in Serbia: current and future regulation, Legal Life, 61(10), 545-561, [in Serbian: Stanivuković, M. (2012). Stranac kao sticalac prava svojine na nekretninama u Srbiji : sadašnje i buduće regulisanje, Pravni život, 61(10), 545-561].

17. Stanivukovic, M., (1996). Property and Other Real Rights of Foreigners in Real Estate in Yugoslavia, Collected Papers of the Law Faculty, Novi Sad, 30(1/3), 277-290. [in Serbian: Stanivuković, M., (1996). Svojina i druga stvarna prava stranaca na nekretninama u Jugoslaviji, Zbornik radova Pravnog fakulteta, Novi Sad, 30(1/3), 277-290].

18. Stabilization and Association Agreement between the European Communities and their Member States, of the one part, and the Republic of Serbia, of the other part, Official Gazette of the RS, International Treaties, no. 83/08, [in Serbian: Sporazum o stabilizaciji i pridruživanju između Evropskih zajednica i njihovih država članica sa jedne strane, i Republike Srbije sa druge strane, Službeni glasnik RS, Međunarodni ugovori, br. 83/08].

19. Spalevic, N. (2013/2014). Hungary, Student Journal of Commercial Law, 4(1), 108-112. [in Serbian: Spalević, N. (2013/2014). Mađarska, Studentska revija za privredno pravo, 4(1), 108-112].

20. Case C-370 0C Criminal proceedings against UWE KAY Festersen (2013/2014). Student's Journal of Commercial Law, 4(1), 23-27. [in Serbian: Slučaj C-370 0C Krivični postupak protiv UWE KAY Festersen-a (2013/2014). Studentska revija za privredno pravo, 4(1), 23-27].

21. Stojanovic, D., \& Pop Georiev, D. (1980). Commentary on the Law on Basic Property Relations. Official Gazette of the SFRY, Belgrade. [in Serbian: Stojanović, D., Pop Georiev, D. (1980). Komentar Zakona o osnovnim svojinsko-pravnim odnosima. Službeni list SFRJ, Beograd].

22. Trgovčevic-Prokic, M., \& Pocuca, M. (2016). Agricultural land expropriation. Economics of Agriculture, 63(4), 1281-1295. [in Serbian: Trgovčević-Prokić, M., Počuča, M. (2016). Eksproprijacija poljoprivrednog zemljišta. Ekonomika poljoprivrede, 63(4), 1281-1295].

23. Regulation on the Acquisition of Rights on Buildings and Flats and Land by Foreign Nationals and Foreign Legal Entities, Official Gazette of the SFRY, no. 53/62. [in Serbian: Uredba o sticanju prava na zgradama i stanovima i zemljištima od strane stranih državljana i stranih pravnih lica, Služneni list SFRJ, br. 53/62].

24. Constitution of the Republic of Serbia, Official Gazette of the RS, no. 98/06. [in Serbian: Ustav Republike Srbije, Službeni glasnik RS, br. 98/06].

25. Varadi, T. (1987). Private international law. Forum, Novi Sad. [in Serbian: Varadi, T. (1987). Međunarodno privatno pravo. Forum, Novi Sad]. 
26. Vukićević, S., Stepić, D., \& Savović, D. (2011). Property rights of foreigners on agricultural land in the Republic of Serbia, Economics of Agriculture, 58(4), 529546. [in Serbian: Vukićević, S., Stepić, D., Savović, D. (2011). Svojinskopravna ovlašćenja stranaca na poljoprivrednom zemljištu u Republici Srbiji, Ekonomika poljoprivrede, 58(4), 529-546].

27. Law on Basic Property-Legal Relations, Official Gazette of the SFRY, no. 6/80, Official Gazette SRY, no. 3/90, no. 29/96 and Official Gazette RS, no. 115/2005 other law. [in Serbian: Zakon o osnovnim svojinsko-pravnim odnosima, Službeni list SFRJ, br. 6/80, Službeni list SRJ, br. 3/90, br. 29/96 i Sl. glasnik RS, br. 115/05 - dr. zakon].

28. Law on Inheritance of 1955, Official Gazette of the FPRY, no. 20/55. [in Serbian: Zakon o nasleđivanju iz 1955, godine, Službeni list FNRJ, br. 20/55].

29. Law on Settlement of Conflicts of Laws with Regulations of Other Countries, Official Gazette of the SFRY, no. 43/82 and 72/82 - ed., Official Gazette FRY, no. 46/96 and the Official Gazette of the RS, no. 46/06 - other law. [in Serbian: Zakon o rešavanju sukoba zakona sa propisima drugih zemalja, Službeni list SFRJ, br. 43/82 i 72/82 - ispr., Službeni list SRJ, br. 46/96 i Službeni glasnik RS, br. 46/06 dr. zakon].

30. Law on Foreigners, Official Gazette of the RS, no. 24/18, 31/19. [in Serbian: Zakon o strancima, Službeni glasnik RS, br. 24/18, 31/19].

31. Law on Investments, Official Gazette of the RS, no. 89/15, 95/18. [in Serbian: Zakon o ulaganjima, Službeni glasnik $R S$, br. 89/15, 95/18].

32. Law on Inheritance, Official Gazette of the RS, no. 46/95, 101/03 - USRS decision and 6/15. [in Serbian: Zakon o nasleđivanju, Službeni glasnik RS, br. 46/95, 101/03 - odluka USRS i 6/15].

33. Law on turnover of land and buildings, Official Gazette SFRY, no. 19/155, 1/67, 11/74. [in Serbian: Zakon o prometu zemljišta i zgrada, Službeni list FNRJ, br. $19 / 155,1 / 67,11 / 74]$.

34. Law on Amendments to the Law on Agricultural Land, Official Gazette of the RS, no. 80/2017. [in Serbian: Zakon o izmenama i dopunama Zakona o poljoprivrednom zemljištu, Službeni glasnik RS, br. 80/17].

35. Law on Foreign Trade of the RS, Official Gazette of the RS, no. 36/09, 36/11, other law and 88/11. [in Serbian: Zakon o spoljnotrgovinskom poslovanju RS, Službeni glasnik RS, br. 36/09, 36/11, dr. zakon i 88/11].

36. Law on Agricultural Land, Official Gazette of the RS, no. 62/06, 65/08 - other law, 41/09, 112/15, 80/17 and 95/18 - other law. [in Serbian: Zakon o poljoprivrednim zemljištem, Službeni glasnik RS, br. 62/06, 65/08 - dr. zakon, 41/09, 112/15, 80/17 i 95/18 - dr. zakon]. 